\title{
Effects of Caffeine on the Organism-Literature Review
}

\author{
Marcio Antonio Ferreira Camargo, Carmen Aparecida Cardoso Maia Camargo \\ Academic Unit of Passos, University of State of Minas Gerais, Passos, Brazil \\ Email: mcamargo2004@yahoo.com.br,kkcamargo@yahoo.com.br
}

How to cite this paper: Camargo, M.A.F. and Camargo, C.A.C.M. (2019) Effects of Caffeine on the Organism-Literature Review. Open Access Library Journal, 6: e5265.

https://doi.org/10.4236/oalib.1105265

Received: February 19, 2019

Accepted: March 5, 2019

Published: March 8, 2019

Copyright $\odot 2019$ by author(s) and Open Access Library Inc.

This work is licensed under the Creative Commons Attribution International License (CC BY 4.0).

http://creativecommons.org/licenses/by/4.0/

(c) (i) Open Access

\begin{abstract}
Caffeine is the most widely consumed stimulant. Caffeine is known to increase energetic metabolism throughout the brain, but it also decreases cerebral blood flow, inducing relative cerebral hypoperfusion. Caffeine activates norepinephrine neurons and appears to affect the local release of dopamine. Many of the warning effects of caffeine may be related to the action of methylxanthine on serotonin neurons. In this sense, this study aimed to identify the main effects of caffeine on the body. This is a literature review study addressing the main effects of caffeine on the body. In order to select the studies, an online survey of articles has been conducted on sites such as the Scientific Electronic Library Online (SciELO), Medical Literature Analysis and Retrieval System Online (MEDLINE) and Latin American and Caribbean Literature in Health Sciences (LILACS), using the descriptors "caffeine", "effects of caffeine" and "methylxanthine". We included the studies published between the years 2000 to 2018, which explicitly contemplate the evaluated aspects. In general, caffeine has effects on anxiety and sleep that vary according to individual sensitivity to methylxanthine. The central nervous system does not appear to develop a great tolerance to the effects of caffeine, although the symptoms of dependence and withdrawal are reported.
\end{abstract}

\section{Subject Areas}

Public Health

\section{Keywords}

Caffeine, Effects of Caffeine, Methylxanthine

\section{Introduction}

Coffee is the most consumed beverage in the world. Caffeine has been used as a 
drug for thousands of years. There are several plants that contain the substance that was grown or harvested, but today caffeine is added to many foods. Despite the increased use of caffeine in recent times, many people have little knowledge of the general effects it has on their bodies.

Caffeine, a xanthine alkaloid, was first identified in coffee. Therefore, it is the active ingredient in coffee, but it can be present in many foods and beverages. This substance belongs to the group of compounds of methylxanthines, which also includes tea. Xanthines are substances capable of stimulating the nervous system, producing a certain alertness of short duration.

In addition to coffee, caffeine is also found in other drinks, in smaller proportions, such as those containing cocoa, cola and chocolate; in addition to tea and some analgesic or cold remedies. Due to the diversity of products containing caffeine, it is, without a doubt, the most popular psychoactive drug in the world.

Considering that caffeine is present in coffee, tea, chocolates, caffeine-based soft drinks or medicines, it can be said that in general the population makes use of this substance daily, although it is very difficult to quantify its consumption.

\section{Materials and Methods}

This is a systematic review of the literature, in order to search for articles in the literature, to analyze and identify the main effects of caffeine on the body.

Galvão and Pereira (2014) [1] understand that systematic reviews differ from narrative or traditional revisions. These are broad and provide general information on the subject in question. They are also distinguished from integrative reviews, in which different designs are used in the same research, in addition to expressing the author's own opinion. Systematic reviews are considered secondary studies, which have in their primary studies their data source.

According to Muñoz (2002) [2], the systematic review is a method that has been increasingly used in scientific research for the evaluation of a data set simultaneously, given the ability to integrate the findings of existing individual research, allowing, in an objective way, the synthesis of scientific information.

In order to select the studies, an online survey of articles published in the Scientific Electronic Library Online (SciELO), Medical Literature Analysis and Retrieval System Online (MEDLINE) and Latin American and Caribbean Literature in Health Sciences (LILACS), using the descriptors "caffeine", "effects of caffeine" and "methylxanthine". We included the studies published between the years 2000 to 2018, which explicitly contemplate the evaluated aspects.

The descriptors used allowed the collection of scientific articles used in the review. After the search with the descriptors in the databases, a total of 28 articles were found in the Portuguese language. However, from this total, animal studies and studies that did not refer to the central nervous system, effects on the organism, performance, memory, blood pressure and ergogenic potential were excluded. Through this process, the final sample consisted of eight articles, as shown in Table 1. 
Table 1. Identification of articles.

\begin{tabular}{ll}
\hline Title/Year & \multicolumn{1}{c}{ Objectives } \\
\hline & $\begin{array}{l}\text { The present work has as main objective to show } \\
\text { medications with pure caffeine or in combinations }\end{array}$ \\
$1 \quad$ Effect of Caffeine & $\begin{array}{l}\text { and their analgesic effects, supplements for physical } \\
\text { activities used by athletes, foods, and adverse effects } \\
\text { on the central nervous system. }\end{array}$
\end{tabular}

2 Caffeine Consumption-2000

To evaluate values for the caffeine content in food products.
3

Caffeine and Its Effects on Evaluation of the effects of caffeine on health. Health-2018
Magazine article.
This article presents a literature review about the

Major Compounds Profiles in most common components present in energy drinks:

Energetic Drinks: Caffeine,

Taurine, Guarana, and

Glucoronolactone-2006

Coffee, Caffeine vs. Health

5

Review of the Effects of

Coffee Consumption on

Health-2010

Influence of Caffeine on

6 Blood Pressure and Platelet Aggregation Behavior-2000

Ergogenic Effect of Caffeine

7

on Performance in Medium

and Long-Term

Exercises-2005

Cardiovascular Effects of

8 Caffeine:

Literature Review-2013

caffeine, taurine, guarana and glucuronolactone, with emphasis on Brazilian legislation, composition, action on the organism, toxicological and metabolic aspects.

This article seeks to sensitize people in making a conscious decision regarding consumption.

Considering the high consumption in Brazil and in pressure and platelet aggregation.

To analyze the effects of caffeine on performance in medium and long term exercises. the world population of products containing caffeine hypertensive effect that disappears with chronic use. in its composition, the authors proposed to observe The absence of alterations in platelet aggregation the effects of this substance on the behavior of blood points to the need for studies with a greater number of participants and in a randomized way.

The findings point to caffeine as an efficient ergogenic agent in medium and long-term exercise. The ergogenic effect of caffeine on performance has been

evidenced after the acute intake of caffeine doses between 3 and $6 \mathrm{mg} / \mathrm{kg}$ body weight. However, it still does not seem clear what caffeine action mechanisms would be involved in improving performance in prolonged exercise

As shown in several studies, it is a fact that caffeine alters some of the factors that influence cardiovascular health, such as plasma homocysteine levels, serum cholesterol, heart rate, and blood pressure. However, the magnitude of these alterations, against a risk of cardiovascular death.

\section{Results and Discussion}

The evaluation of the articles consisted in reading the study in its entirety 
through the technique of content analysis and the following important points were defined: 1) caffeine; 2) Caffeine actions on the body and 3) side effects with excess caffeine intake.

\subsection{Caffeine}

Caffeine is the drug of greatest employment, the highest social acceptance and most widely used in the world. In its natural sources, caffeine has been consumed by man throughout the world for centuries. It is consumed regularly by billions of people, configuring diverse and varied cultural practices, and is even vital for some economies.

Caffeine, chemically known as 1,3,7-trimethylxanthine, is the active ingredient in coffee, but it can be present in many foods and beverages. This substance belongs to the group of compounds of methylxanthines, which also includes tea. Xanthines are substances capable of stimulating the nervous system, producing a certain alertness of short duration. Today caffeine is regularly consumed by billions of people around the world, configuring diverse and varied cultural practices, and is even vital for some economies [3].

According to Roberts HR, Barone JJ (1983, apud Carvalho et al., 2006) [4], since its chemical isolation in 1820 , caffeine has been found to be a stimulant in a variety of medicines used as analgesics, diuretics, weight allergy-relieving preparations.

\subsection{Caffeine Actions on the Body}

Caffeine has a significant participation in the mechanism involving the actions of the central and peripheral system, resulting in changes in the metabolic and physiological processes.

According to Revista TodaBiologia.com. (2018) [5], in the article entitled "Caffeine and its effects on health", stresses that:

Researchers at the Harvard School of Public Health have released studies in July 2013 that show that caffeine not only stimulates the central nervous system but can also act as a mild antidepressant, boosting the production of certain neurotransmitters (serotonin, noradrenaline) in the brain. The researchers also concluded that the suicide risk for adults who ate 2 to 4 cups of coffee per day was 50 percent lower than those who drank decaffeinated coffee or too little or no coffee (source: Harvard Gazette, July 2013).

In view of this, we can affirm that caffeine affects normal cellular function and has several physiological effects. It is a Central Nervous System (CNS) stimulant and, depending in part on the amount consumed, can produce a variety of effects on other organs.

According to Carvalho et al. (2006) [6], in his researches, emphasizes that:

in the central nervous system, more precisely in the autonomic nervous system, the neurotransmitter system based on the neurotransmitter adeno- 
sine acts as a reducer of heart rate, blood pressure and body temperature. Caffeine exerts an inhibitory action on neurotransmitter adenosine receptors, located in nerve cells. Many of the physiological responses to caffeine administration are opposite to those of adenosine, so there is a feeling of re-energizing, decreased sleep, and fatigue. Caffeine has an effect on the release of nerve cells and the release of some other neurotransmitters and hormones, such as adrenaline.

The effects of caffeine on the body are numerous, so it is a stimulation of the central nervous system that increases organic activity and streamlines mental and bodily and mental functions.

In relation to intellectual performance, coffee consumption increases short-term memory, facilitates the memorization process because it improves concentration, helps maintain mental acuity and reduces cognitive deterioration in the elderly [7].

According to Cavalcante (2000) [8], studies have shown that methylxanthines, such as caffeine, are competitive antagonists of A1 and A2 adenosine receptors found in the brain, heart, lungs, peripheral vessels and platelets. The effects of caffeine on blood pressure are controversial. Some research suggests that its action on peripheral vascular resistance is less intense than its effect on the central nervous system, the latter being primarily responsible for the increase in peripheral vascular resistance.

On the other hand, caffeine is a substance that has been used by sportspeople for the purpose of improving physical performance. Its ergogenic potential has been tested in physical exercises of different natures. It is believed that caffeine has central and peripheral mechanisms of action that can excite or restore cerebral and bulbar functions, as well as trigger important metabolic and physiological changes that would improve athletic performance. Despite the lack of consensus among researchers on the effectiveness of caffeine use for optimizing physical performance, numerous athletes have used this substance, however, without the necessary care, which can contribute to the appearance of undesirable side effects, putting in risk, mainly, the physical integrity of these individuals [9].

According to the authors cited, caffeine can provide an increase in muscle strength accompanied by a greater resistance to the installation of the process of muscle fatigue. It is still not fully understood which mechanism of action responsible for the increase in muscle strength, however, it is believed that this occurs more strongly by the direct action of caffeine in the Central Nervous System than by its action at the peripheral level.

The possibility of improving physical performance has led to this alkaloid being placed on the list of substances banned by the International Olympic Committee (IOC), which set the limit of $12 \mu \mathrm{g} / \mathrm{mL}$ caffeine in urine as a parameter for doping detection. Some studies have shown that these levels can be achieved with the intake of approximately $9 \mathrm{mg}$ of caffeine per kilogram of body weight. 
However, recent statistics have shown improvement in athletic performance with intake of only 3 to $6 \mathrm{mg}$ of caffeine per kilogram of body weight [9].

\subsection{Side Effects of Caffeine Intake}

According to Altimari et al. (2005) [9], the effect of caffeine varies from person to person, taking into account its weight and its regularity in intake. It is believed that the habituation of this substance is possible from the chronic intake of $100 \mathrm{mg} /$ day of caffeine which is equivalent to approximately one and a half cups of $150 \mathrm{ml}$ instant coffee, three and a half cups of $150 \mathrm{ml}$ instant tea, three bars of $160 \mathrm{~g}$ of milk chocolate, two cans of $350 \mathrm{ml}$ of glue-based soft drink or one can and half of Red Bull ${ }^{\circledR}$ energy drink. With this dosage, the expected effects are neutralized, but if habitual users, stay four days without ingesting the caffeine, they lose that adaptation.

According to Almeida, Pereira and Moreira (2013) [10], several studies have shown that it is a fact that caffeine alters some of the factors that influence cardiovascular health, such as plasma homocysteine levels, serum cholesterol levels, heart rate in addition to blood pressure. However, the magnitude of these changes, against a risk of cardiovascular death, still proves to be minimal, preventing us from gauging any judgment that caffeine may be a beneficial substance or not.

The authors mentioned above emphasize that in relation to the changes in cardiac electrical conduction, the researches developed so far and several reports of cases present in the literature show varying results, sometimes even contradictory results. With this, the medical class still does not have sufficient evidence to indicate a change in the habits of use of the caffeine.

\section{Conclusions}

The objective of this study was to identify the main effects of caffeine on the body, a substance found in various food products like coffee and chocolate, consumed worldwide and used by athletes as food supplement as well.

According to the literature, it can be confirmed that caffeine directly interferes with the central nervous system.

It can be affirmed that the moderate consumption of coffee does not represent a risk to health, presenting a protective effect in several pathologies. The proven benefits of coffee justify its inclusion in the functional foods group, not only for caffeine but also for other compounds present in coffee.

Current evidence has shown moderate consumption of caffeine is a therapeutic resource as it promotes physical and mental performance. However, further studies, with an emphasis on neurobiology, will be needed to elucidate the potential abusive effect on caffeine use, its risks and benefits.

\section{Conflicts of Interest}

The authors declare no conflicts of interest regarding the publication of this paper. 


\section{References}

[1] Galvão, T.F. and Pereira, M.G. (2014) Revisões sistemáticas da literatura: Passos para asua elaboração. Epidemiologia e Serviços em Saúde, 23, 183-184. https://doi.org/10.5123/S1679-49742014000100018

[2] Muñoz, S.I.S., Takayanagui, A.M.M., dos Santos, C.B. and Sanchez-Sweatman, O. (2002) Systematic Literature Review and Meta-Analysis: Basic Notions about Its Design, Interpretation and Application in Health Research. Brazilian Nursing Communication Symposium, São Paulo, 8 May 2002.

http://www.proceedings.scielo.br/scielo.php?script=sci_arttext\&pid=MSC00000000 52002000200010\&lng=en\&nrm=abn

[3] Santos, A.L.P., Santos, C.O., Rosa, N.R., Souza, P. and Mazeto, T.K. (2015) Efeito da cafeína no organismo. Rev. Saberes, Rolim de Moura, 3, 45-52. https://facsaopaulo.edu.br/wp-content/uploads/sites/16/2018/05/ed3especial/5.pdf

[4] Barone, J.J. and Roberts, H.R. (1996) Caffeine Consumption. Food and Chemical Toxicology, 34, 119-129. https://doi.org/10.1016/0278-6915(95)00093-3

[5] REVISTA TODABiOlOGiA.COM. (2018) Cafeina e seus efeitos na Saúde. https://www.todabiologia.com/saude/cafeina.htm

[6] Carvalho, J.M., Maia, G.A., Sousa, P.H.M. and Rodrigues, S. (2006) Perfil dos principais componentes em bebidas energéticas: Cafeína, taurina, guaraná e glucoronolactona. Rev Inst Adolfo Lutz, 65, 78-85.

http://periodicos.ses.sp.bvs.br/pdf/rial/v65n2/v65n2a02.pdf

[7] Prada, D.M.R. (2010) Café, cafeína vs. Salud. Revisión de los efectos del consumo de café en la salud. Sección artículos de revisión de tema. Universidad y Salud, 12, 156-167.

http://www.scielo.org.co/scielo.php?pid=S0124-71072010000100017\&script=sci_abs $\underline{\text { tract\&tlng }=\text { es }}$

[8] Cavalcante, J.W.S., Santos Jr., P.R., Menezes, M.F.F., Marques, H.O., Cavalcante, L.P. and Pacheco, W.S. (2000) Influência da Cafeína no Comportamento da Pressão Arterial e da Agregação Plaquetária. Arq Bras Cardiol, 75, 97-101. http://publicacoes.cardiol.br/abc/2000/7502/75020002.pdf

[9] Altimari, L., Melo, J., Trindade, M., Tirapegui, J. and Cyrino, E. (2005) Efeito ergogênico da cafeína na performance em exercícios de média e longa duração. Revista Portuguesa de Ciências do Desporto, 5, 87-101. http://www.scielo.mec.pt/pdf/rpcd/v5n1/v5n1a10.pdf

[10] Almeida, D.V.P., Pereira, N.K. and Moreira, D.A.R. (2013) Efeitos Cardiovasculares da Cafeína: Revisão de literatura [Cardiovascular Effects of Caffeine: Literature Review]. Revista Ciências em Saúde, 3.

http://cienciadotreinamento.com.br/wp-content/uploads/2017/12/EFEITOS-CARDI OVASCULARES-DA-CAFE\%C3\%8DNA-REVIS\%C3\%83O-DE-LITERATURA.pdf 